\title{
IDENTIFIKASI PERILAKU KELUARGA SADAR GIZI (KADARZI) PADA BAYI DAN BALITA DI DESA CEPIRING KABUPATEN KENDAL
}

\author{
Sri Setiasih ${ }^{1}$, Titi Mursiti ${ }^{2}$, Supardi ${ }^{3}$, Yulia Ermawati ${ }^{4}$ \\ 1,2,3,4 UPP Kampus Kendal, Poltekkes Kemenkes Semarang, Indonesia
}

\begin{abstract}
The first two early years of life is a crucial period because the baby will grow a lot and develop quickly. Malnutrition in the first two years of life will be permanent, irreversible eventhough the nutritional needs of the next period has been given. The member of family must practice health All the family member implement nutrititonal behaviour to prevent he occuurencess of malnutrition and they are able to overcome the problem of it. The purpose of this study was to identify the levels of nutrittion in infants and toddlers in Cepiring Village Kendal Regency. This research is a descriptive research. The approach used is the survey approach. Respondents who were the subject of this study were families who have babies and toddlers aged 0-59 months. The research used cluster sampling technique, the sample was 45 respondents.

The results obtained that 33, 3\% respondents gave breastfeeding exclusively, $93 \%$ consumed healthy food everyday, $61 \%$ respondents used iodize salt for cooking everyday, 91,7\% respondents consumed vitamin $A$ and $94,4 \%$ went to scale the baby weight regularly to the Posyandu. It can be concluded that the familily nutritional behaviour in Cepiring Village is average good. The suggestion to the mothers who have newborn is to exclusively breastfeeding until 6 months old.
\end{abstract}

Keywords: Kadarzi; Vitamin A; Nutritional Behaviour 


\section{PENDAHULUAN}

Masalah gizi ada di hampir semua fase kehidupan, diawali fase di kandungan (janin), fase bayi, fase anak, fase dewasa, sampai kepada orang lanjut usia. Periode dua tahun pertama kehidupan seseorang adalah periode kritis, dimana di masa ini terjadi perkembangan dan perktumbuhan yang sangat pesat. Gangguan gizi yang terjadi pada fase ini bisa menjadi bersifat permanen, tidak dapat disembuhkan walaupun sudah terpenuhinya kebutuhan gizi pada fase selanjutnya. Dalam Suparmanto (2007) disebutkan sebanyak 1,7 juta angka gizi kurang di antaranya adalah masuk kategori gizi buruk. Sekitar 11 juta anak usia sekolah masuk kategori pendek sebagai akibat dari gizi kurang pada fase balita. Sementara masalah gizi kurang dan gizi buruk masih tinggi. (Suparmanto, 2007).

Keluarga sadar gizi (KADARZI) menurut buku Rahmi Utomo, yang berjudul Panduan Umum Keluarga Mandiri Sadar Gizi (KADARZI) adalah keluarga yang seluruh anggota keluarga itu menjalankan perilaku seimbang, dapat mengetahui masalah kesehatan dan gizi bagi setiap anggota keluarga dan dapat mengambil langkah untuk dapat mengatasi masalah gizi yang di jumpai kepada anggota keluarganya. (Untoro, 2002).

Perilaku gizi yang belum baik dapat dilihat dengan rendahnya pemanfaatan fasilitas oleh masyarakat. Menurut data dari Dinas Kesehatan, hanya sekitar 50\% balita yang ditimbang di Posyandu sebagai upaya deteksi dini gangguan pertumbuhan. Sebanyak $74 \%$ bayi dan balita yang telah mendapatkan kapsul vitamin A dan sebanyak $60 \%$ ibu hamil yang mengkonsumsi tablet tambah darah.

Perilaku gizi lainnya yang juga masih belum baik adalah masih rendahnya ibu yang memberikan ASI kepada bayi 0 6 bulan secara eksklusif. Rumah tangga yang menggunakan garam beryodium baru mencapai $39 \%$ dan sekitar $28 \%$ memiliki pola makan yang belum beraneka ragam. Hal-hal yang mempengaruhi kondisi tersebut antara lain adalah tingkat kemampuan ekonomi keluarga dalam penyediaan bahan pangan berdasarkan kebutuhan keluarga, pengetahuan dan perilaku keluarga dalam penentuan, mengolah dan membagi makanan juga mempengaruhi. Keadaan gizi masingmasing individu dipengaruhi oleh asupan gizi dan ada tidaknya penyakit infeksi. Seseorang yang asupan gizinya tidak cukup akan mengalami kekurangan gizi dan mudah sakit, jika seseorang sering sakit akan mengalami gangguan nafsu makan yang apabila dibiarkan akan mengakibatkan gizi kurang. Banyaknya kasus gizi kurang menunjukkan bahwa asupan gizi ditingkat keluarga belum memadai. (Suparmanto, 2007)

KADARZI diprogramkan untuk
menumbuhkan kesadaran akan 
esensialnya gizi bagi kesehatan yang dimulai dari lingkaran terkecil dalam mampu melakukan peran penting dalam penentuan gizi keluarga: (Kemenkes RI, 2013).

Berdasarkan data posyandu di desa Cepiring pada bulan Januari - Februari tercatat 480 balita di posyandu dan 110 diantaranya tidak ditimbangkan ke posyandu secara teratur misal tidak ditimbangkan ke posyandu sebanyak $2 X$ berturut - turut, bahkan banyak juga balita yang tidak ditimbangkan sebanyak $3 X$ berturut-turut, dan 55 balita termasuk bermasalah dengan gizi. untuk itulah penulis ingin meneliti tentang Identifikasi Perilaku KADARZI pada Bayi dan Balita di Desa Cepiring Kabupaten Kendal. Berdasarkan latar belakang yang dipaparkan maka dapat dirumuskan masalah "Bagaimanakah perilaku KADARZI Pada Bayi dan Balita di Desa Cepiring Kabupaten Kendal?"

\section{METODOLOGI PENELITIAN}

Metodologi penelitian adalah kerangka hubungan antara konsep konsep yang ingin diamati atau di ukur melalui penelitian - penelitian yang akan dilakukan. (Suyanto, 2009)

Berdasarkan tujuan penelitian maka disusun kerangka konsep dalam penelitian ini sebagai berikut :
Variabel Independent

Variabel

Identifikasi Perilaku Keluarga sadar gizi :

- Memberikan ASI saja pada bayi sejak lahir (ASI Eksklusif)

- Makan makanan beraneka ragam.

- Menggunakan garam beryodium.

- Mengkonsumsi vitamin A dosis tinggi.

- Menimbang berat badan balita secara teratur.

Gambar 3.1 Kerangka Konsep

Keterangan:

$$
\begin{gathered}
\\
\square=\text { Yang diteliti }
\end{gathered}
$$

Penelitian ini menggunakan desain penelitian Deskriptif yaitu penelitian yang dilakukan dengan tujuan utama untuk membuat gambaran atau deskriptif tentang suatu keadaan secara obyektif. (Suyanto, 2009)

Pendekatan yang digunakan adalah pendekatan survey. Penelitian ini diharapkan memberi gambaran mengenai “perilaku keluarga sadar gizi pada bayi dan balita di Desa Cepiring Kecamatan Cepiring Kabupaten Kendal.

Populasi dalam penelitian ini adalah semua keluarga yang ada di Desa Cepiring Kabupaten Kendal yaitu ibu yang mempunyai bayi dan balita berumur 0 - 59 bulan, pada bulan Mei tahun 2010 sejumlah 480 keluarga. Sampel pada penelitian ini adalah keluarga yang 
mempunyai balita $0-59$ bulan yang ada di Desa Cepiring Kabupaten Kendal pada bulan Mei 2010, Besarnya sampel dalam penelitian ini dihitung menggunakan rumus Prosentase yaitu : Jika subyek kurang dari 100 (<100) lebih baik diambil semua sehingga menjadi penelitian populasi. Tetapi untuk jumlah subyek besar bisa diambil antara $10 \%$ - $15 \%$ atau $20 \%-25 \%$ atau lebih, hal ini bergantung dari :

a. Kemampuan peneliti yang meliputi waktu, tenaga dan dana.

b. Luas tidaknya wilayah pengamatan dari setiap subyek, dimana hal ini menentukan banyak sedikitnya data.

c. Resiko yang akan ditanggung oleh peneliti, tergantung dari besar kecilnya sampel yang digunakan, semakin besar sampel yang digunakan hasilnya akan semakin baik. Dengan pertimbangan diatas sampel dalam penelitian ini diambil $15 \%$ dari jumlah populasi. Jadi jumlah sampelnya 72. disini peneliti menggunakan tehnik cluster sample. (Saryono, 2008)

Teknik pengambilan sampling dengan menggunakan cluster sample, yaitu mengambil sampel dari kelompokkelompok yang dipandang sebagai satu tingkatan yang sama. (Saryono, 2008) Pada penelitian KADARZI ini peneliti menggunakan 72 sampel yang diperoleh dari Desa Cepiring pada RW $1: 9$ responden, RW 2 : 31 responden, RW 3 : 11 responden, RW $4: 21$ responden, yang penulis bagi menjadi tiga kelompok responden yaitu : bayi dari umur 0-6 bulan, bayi dan balita dari umur 7 bulan -2 th, balita dengan umur lebih dari 2 th.

Kriteria Inklusi dalam penelitian ini adaah keluarga yang mempunyai bayi dan balita berumur 0 - 59 bulan. Sedangkan kriteria esklusi dalam penelitian ini adalah Keluarga yang bertempat tinggal didesa Cepiring namun pada saat dilaksanakan penelitian tidak ada ditempat, keluarga yang mempunyai bayi dan balita berumur 0 - 59 bulan namun tidak bersedia untuk menjadi responden, dan pada penelitian ini tidak ada kriteria eksklusi.

Tempat penelitian ini dilaksanakan di posyandu dan dirumah responden yang terletak di Desa Cepiring Kecamatan Cepiring, Kabupaten Kendal.

Ada 2 jenis variabel yaitu variabel bebas dan variabel terikat. Variabel bebas dalam penelitian ini adalah perilaku keluarga sadar gizi, yang meliputi pemberiaan ASI Eksklusif, Makan makanan bervariasi, memakai garam beryodium, meminum vitamin $\mathrm{A}$ dosis tinggi, menimbang berat badan balita secara teratur. Untuk variabel terikat dalam penelitian ini adalah bayi dan balita namun tidak diteliti

\section{HASIL PENELITIAN DAN BAHASAN}

Desa Cepiring berpenduduk 8835 jiwa dengan jumlah Kepala Keluarga sebanyak 2247 yang terdiri dari 4420 jiwa penduduk laki-laki dan perempuan 4415 
jiwa, serta 480 balita, sarana kesehatan yang dimiliki adalah 1 buah PKD, 7 buah posyandu, 2 buah apotik, 1 buah toko obat, seorang bidan desa, seorang dokter praktek dan 5 tenaga paramedis. Penduduk desa Cepiring rata-rata berpendidikan SD sampai SMA. Dan mata pencaharian sebagian besar yaitu buruh / wiraswasta, pedagang, dan pegawai negeri.

\section{Memberikan ASI Eksklusif Pada Bayi Dan Balita Dari Umur 0-59 Bulan}

Dari hasil penelitian berdasarkan bayi dan balita yang diberikan ASI Eksklusif umur 0-59 bulan dapat dilihat pada tabel berikut :

Tabel 1. Distribusi frekuensi perilaku KADARZI berdasarkan yang memberikan ASI Eksklusif pada bayi dan balita dari umur 0-59 bulan di Desa Cepiring Kabupaten Kendal Th 2010.

\begin{tabular}{llll}
\hline No & Kategori & Frekuensi & $(\%)$ \\
\hline 1 & Ya & 24 & 33,3 \\
2 & Tidak & 48 & 66,7 \\
\hline & Jumlah & 72 & 100 \\
\hline
\end{tabular}

Dari tabel diatas dapat dilihat bahwa sebagian besar responden tidak memberikan ASI eksklusif pada bayi dan balitanya yaitu sebanyak 48 responden ( 66,7\% ) dan yang memberikan ASI eksklusif pada bayi dan balita nya sebanyak 24 responden ( $33,3 \%)$.

Memberikan ASI eksklusif yaitu bayi hanya diberikan ASI saja, tanpa tambahan cairan lain seperti susu formula, jeruk, madu, air teh dan air putih. (Kristiyansari, 2009)

Disini banyak responden yang tidak memberikan ASI eksklusif pada bayi dan balitanya, hal ini dimungkinkan karena perilaku ibu yang berpendapat jika bayi mereka menangis terus menerus berarti lapar dan ASI saja tidak cukup sehingga diberikan makanan berupa nasi dan pisang yang dihaluskan, juga karena tingkat pengetahuan ibu yang kurang sehingga kemungkinan ibu kurang memahami betapa bahayanya memberikan makanan pada bayi yang baru berumur beberapa hari dan kemungkinan ibu juga belum memahami manfaat dari ASI sehingga mereka memberikan makanan pada bayi yang menangis terus - menerus.

\section{Makan makanan beraneka ragam}

Dari hasil penelitian berdasarkan keluarga yang mengkonsumsi makanan 4 sehat setiap hari dapat dilihat pada tabel berikut :

Tabel 2. Distribusi frekuensi perilaku KADARZI berdasarkan yang mengkonsumsi makanan empat sehat setiap hari di Desa Cepiring Kabupaten Kendal Th 2010.

\begin{tabular}{llll}
\hline No & Kategori & Frekuensi & $(\%)$ \\
\hline 1 & Ya & 67 & 93 \\
2 & Tidak & 5 & 7 \\
\hline & Jumlah & 72 & 100 \\
\hline
\end{tabular}


Dari tabel diatas dapat dilihat bahwa sebagian besar keluarga mengkonsumsi makanan 4 sehat sebanyak 67 responden (93\%) dan yang tidak mengkonsumsi makanan 4 sehat setiap harinya sebanyak 5 responden ( $7 \%$ ). Makan makanan beraneka ragam yaitu makan 2 - 3 kali sehari yang terdiri dari 4 macam bahan makanan (makanan pokok, lauk pauk, sayuran, dan buah - buahan). Nampaknya kesadaran akan perilaku keluarga sadar gizi di desa Cepiring untuk mengkonsumsi makanan beraneka ragam cukup baik, ini dimungkinkan karena ibu dan keluarga memhami akan manfaat mengkonsumsi makanan 4 sehat setiap hari, yang diantaranya untuk melengkapi zat-zat gizi yang diperlukan oleh tubuh agar dapat melakukan pekerjaan sehari-hari dan terhindar dari penyakit kekurangan gizi.

\section{Menggunakan garam beryodium}

Dari hasil penelitian berdasarkan keluarga yang menggunakan garam beryodium untuk memasak setiap hari dapat dilihat pada tabel berikut :

Tabel 3. Distribusi frekuensi perilaku KADARZI berdasarkan yang menggunakan garam beryodium untuk memasak setiap hari di Desa Cepiring Kabupaten Kendal Th 2010.

\begin{tabular}{llll}
\hline No & Kategori & Frekuensi & $(\%)$ \\
\hline 1 & Ya & 61 & 84,7 \\
2 & Tidak & 11 & 15,3 \\
\hline & Jumlah & 72 & 100 \\
\hline
\end{tabular}

Dari tabel diatas dapat dilihat bahwa sebagian besar keluarga yang menggunakan garam beryodium untuk memasak setiap hari sebanyak 61 responden ( $84,7 \%$ ) dan yang tidak menggunakan garam beryodium sebanyak 11 responden (15,3\% ).

Garam beryodium adalah garam yang telah diperkaya dengan yodium yang dibutuhkan tubuh untuk pertumbuhan dan kecerdasan. (Kemenkes RI, 2011)

Kesadaran akan perilaku keluarga sadar gizi di desa Cepiring untuk menggunakan garam beryodium cukup baik, ini dimungkinkan karena ibu menyadari bahwa memasak menggunakan garam beryodium jauh lebih banyak manfaatnya dari pada garam rosok, yang antara lain manfaatnya mencerdaskan anak dan mencegah Terjadinya penyakit akibat kekurangan yodium, serta garam beryodium juga sudah banyak dijual diwarung- warung sehingga ibu lebih mudah dalam memperolehnya.

\section{Mengkonsumsi vitamin A dosis tinggi}

Dari hasil penelitian berdasarkan bayi dan balita responden yang mendapatkan kapsul vitamin A dosis tinggi dapat dilihat pada tabel berikut:

Tabel 4. Distribusi frekuensi perilaku KADARZI berdasarkan bayi dan balita responden yang mendapatkan kapsul 
vitamin A dosis tinggi di Desa Cepiring Kabupaten Kendal Th 2010.

\begin{tabular}{llll}
\hline No & Kategori & Frekuensi & $(\%)$ \\
\hline 1 & Ya & 66 & 91,7 \\
2 & Tidak & 6 & 8,3 \\
\hline & Jumlah & 72 & 100 \\
\hline
\end{tabular}

Dari tabel diatas dapat dilihat bahwa sebagian besar bayi dan balita responden mendapatkan kapsul vitamin A dosis tinggi yaitu sebanyak 66 responden ( 91,7\% ) dan yang tidak mendapatkan kapsul vitamin A dosis tinggi sebanyak 6 responden $(8,3 \%)$.

Vitamin A menjadi zat gizi penting yang larut dalam lemak dan disimpan dalam hati, namun tidak dapat diproduksi oleh tubuh, sehingga harus dipenuhi dari luar tubuh (essensial). Vitamin A berguna untuk penglihatan, pertumbuhan dan meningkatkan daya tahan tubuh terhadap penyakit. (M.Nurs, Nursalam, 2005)

Bayi dan balita responden cukup banyak yang mendapatkan kapsul vitamin A dosis tinggi meskipun belum keseluruhan dapat, ini dikarenakan keaktifan para tenaga kesehatan dan bidan desa Cepiring yang selalu membagikan progam vitamin $\mathrm{A}$ dari pemerintah setiap bulan februari agustus, meskipun saat pembagian vit A ada balita yang tidak ditimbangkan ke posyandu, vitamin A tersebut tetap dibagikan kerumah - rumah balita yang tidak berangkat oleh kader.

\section{Menimbang BB Balita Secara} Teratur

Menurut hasil penelitian berdasarkan balita yang ditimbangkan BB nya secara teratur dapat dilihat pada tabel berikut :

Tabel 5. Distribusi frekuensi perilaku KADARZI berdasarkan yang menimbang berat badan bayi dan balita secara teratur di Desa Cepiring Kabupaten Kendal Th 2010.

\begin{tabular}{llll}
\hline No & Kategori & Frekuensi & $(\%)$ \\
\hline 1 & Ya & 68 & 94,4 \\
2 & Tidak & 4 & 5,6 \\
\hline & Jumlah & 72 & 100 \\
\hline
\end{tabular}

Dari tabel 5 diatas dapat dilihat bahwa sebagian besar responden menimbang BB balitanya secara teratur yaitu sebanyak 68 responden $(94,4 \%)$ dan yang tidak menimbangkan BB balitanya secara teratur ada 4 responden $(6,7 \%)$.

Berat badan menjadi indikator sederhana di lapangan atau puskesmas untuk menunjukan status gizi anak, yaitu dengan menggunakan kartu menuju sehat. (Suyanto, 2009 )

Nampaknya kesadaran akan perilaku keluarga sadar gizi di desa Cepiring untuk menimbangkan berat badan bayi dan balitanya sudah cukup baik, ini dikarenakan ibu dan keluarga kemungkinan sadar akan pentingnya memantau pertumbuhan bayi dan balita salah satunya dengan menimbangkan balitanya ke posyandu, kemungkinan 
keluarga meyakini bahwa banyak manfaat dengan menimbangkan balita mereka yaitu diantaranya Sebagai informasi mengenai keadaan gizi, pertumbuhan dan kesehatan anak, karena diposyandu selain bayi dan balita ditimbang, bagi ibu juga diberikan penyuluhan dan kadang - kadang juga bayi dan balita diberi PMT

\section{KESIMPULAN}

Berdasarkan hasil penelitian tentang Identifikasi perilaku keluarga sadar gizi pada bayi dan balita di desa Cepiring kabupaten kendal dapat ditarik kesimpulan sebagai berikut :

1. Responden yang tidak memberikan ASI eksklusif pada bayi dan balita dari umur 0 - 59 bulan yaitu 48 responden ( 66,7 \%), dan yang memberikan ASI eksklusif 24 responden (33,3\%).

2. Sebagian besar responden sudah mengkonsumsi makanan 4 sehat setiap harinya yaitu 67 responden ( $93 \%$ ), dan yang tidak mengkonsumsi makanan 4 sehat setiap harinya 5 responden ( $7 \%$ ).

3. Sebagian besar responden sudah menggunakan garam beryodium untuk memasak setiap harinya yaitu 61 responden ( $84,7 \%$ ), dan yang tidak menggunakan garam yodium 11 responden ( $15,3 \%$ ).

4. Sebagian besar responden sudah mendapatkan kapsul vitamin A dosis tinggi yaitu 66 responden ( 91,7\%), dan yang belum mendapatkan kapsul vitamin A 6 responden ( 8,3\%).

5. Responden yang menimbangkan berat badan balitanya secara teratur ke posyandu yaitu 68 responden ( $94,4 \%)$, dan yang tidak teratur ada 4 responden ( $5,6 \%$ ).

Dari penelitian ini, saran yang didapatkan adalah :

1. Bagi ibu yang mempunyai bayi dan balita

Disarankan hanya memberikan ASI saja sampai bayi berumur 6 bulan (ASI Eksklusif).

2. Bagi tenaga kesehatan

Memberikan penyuluhan tentang program gizi bagi keluarga, dengan meningkatkan parilaku keluarga sadar gizi pada bayi dan balita khususnya dalam pemberian ASI eksklusif.

\section{DAFTAR PUSTAKA}

Ari kunto, Suharsimi. 2006. Prosedur Penelitian Suatu Pendekatan. Jakarta : Rineka Cipta.

Dinkes. 2013. Keluarga Sadar Gizi (KADARZI Mewujudkan Keluarga Cerdas Dan Mandiri. Jakarta. Kemenkes RI.

Hernawati, Ina. 2009. Apa dan mengapa tentang vitamin $A$. Jakarta:Departemen Kesehatan RI.

Kementrian Kesehatan RI. 2011. Buku Panduan Kader Posyandu \& Menuju keluarga sadar gizi. Jakarta : Kementrain Kesehatan RI.

Kristiyansari, Weni. 2009. ASI, Menyusui dan Sadari. Yogjakarta : Nuha Medika. 
M.Nurs, Nursalam Dr. 2005. Asuhan Keperawatan Bayi dan Anak. Jakarta : Salemba Medika.

Notoatmojo, Soekidjo. 2005. Metodologi Penelitian Kesehatan. Jakarta : Rineka Cipta.

Saryono. 2008. Metodologi Penelitian Kesehatan.Yogjakarta:Mitra Cendekia Press.

Suparmanto, Sri Astuti. 2007. Pedoman Strategi Kie Keluarga Sadar Gizi (KADARZI). Jakarta : Departemen Kesehatan.

Suyanto dkk. 2009. Riset Kebidanan.Yogjakarta:Mitra Cendekia.

Untoro, Rahmi. 2002. Panduan Umum Keluarga Mandiri Sadar Gizi (KADARZI). Jakarta : Departemen Kesehatan. 